\title{
EFFECT OF DIETARY ZINC SUPPLEMENTATION ON REPRODUCTIVE PERFORMANCE \\ OF ZARAIBI MALE GOATS
}

(With 3 Tables)

By

MAHA S. ZIADA and M.A. HEGAZY

(Received at 13/3/2004)

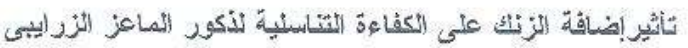

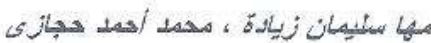

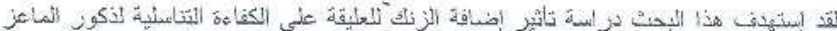

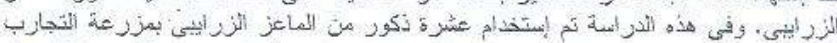

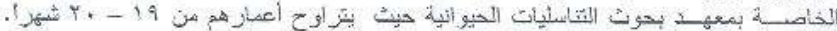

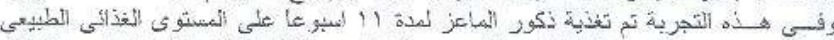

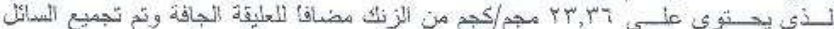

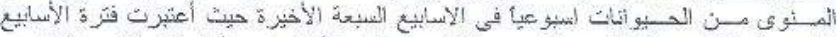

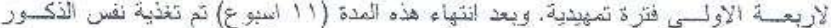

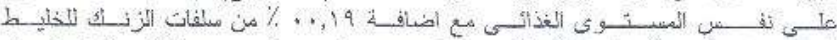

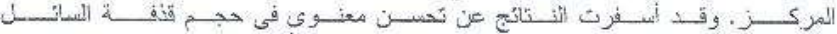

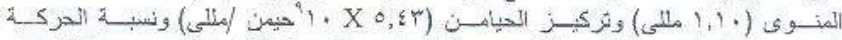

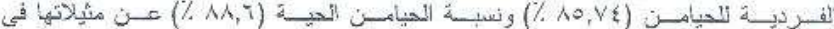

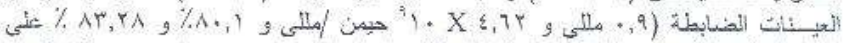

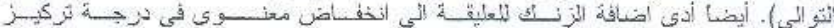

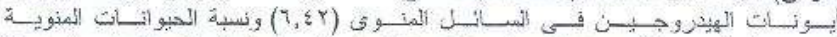

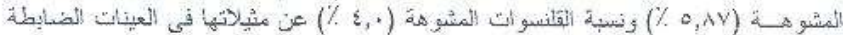

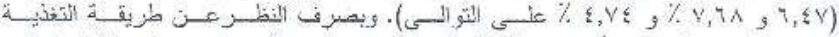

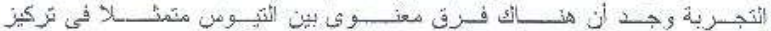

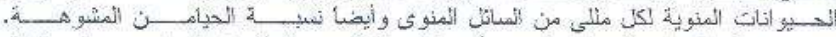

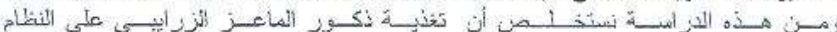

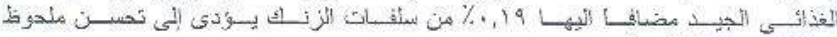

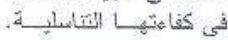




\section{SUMMARY}

Ten Zaraibi male goats aged $19-20$ months were used in the present study. They were kept at the experimental farm of Anim. Reprod. Res. Instit. Al-Ahram, Giza Province. They were fed for 11 weeks on a basal diet containing about $23.36 \mathrm{mg} / \mathrm{kg}$ zinc on dry matter basis. Semen collection was carricd out weekly along the last 7 wecks, where the first 4 weeks was considered as an adaptation period. After the end of the 11 weeks. the same animals were fed on the same diet supplemented with $0.19 \%$ of zinc sulphate added to the concentrate mixture. The results revealed a sionificant $(\mathrm{P}<0.05)$ improvement in semen volume $(1.10 \mathrm{ml})$ sperm concentration $\left(5.43 \times 10^{\%} / \mathrm{ml}\right)$, percentage of individual sperm motility $(85.74 \%)$ and percentage of live spermatozoa $(88.6 \%)$ in treated than that for pre-treated samples $\left(0.90 \mathrm{ml}, 4.62 \times 10^{9} / \mathrm{ml}, 80.1 \%\right.$ and $83.28 \%$, respectively). On the contrary, $\mathrm{pH}(6.42)$, percentages of abnormal spermatozoa $(5.87 \%)$ and those with acrosomal defects $(4.0 \%)$ were decreased significantly $(\mathrm{P}<0.05$ ) by adding zinc to the ration of tested bucks than those determined in pre-zinc addition samples (6.47, $7.68 \%$ and $4.74 \%$, respectively). Buck individualities were found prominent for some parameters; sperm concentration and percentages of abnormal spermatozoa. $(\mathrm{P}<0.05)$. It can be concluded that dietary zinc supplementation is effective in improving semen quality of Zaraibi goats.

Key words: Zine supplementation, reproductive performance,

$$
\text { zaraibi male goats }
$$

\section{INTRODUCTION}

The wide distribution of goats in the tropics and sub-tropics reflects their ability to adapt to a variety of enviromments. The inherent characteristics of goats such as resistance to dehydration, preference for browse and wide-ranging feeding habits, enable them to thrive in regions with very little rainfall (Chehadah et al. 2001).

In less developed countrics, it is easier to increase the population and productivity of goats, which can overcome the increase demand for additional animal protein feed. Livestock-production efficiency is largely dependent on reproductive performance. Several factors are known to affect the reproductive potential of farm animals, one of which is the nutritional factor (Mahmoud, 2001). Under-nutrition and deficiency of specific nutrients could interfere with the synthesis of 
hormones involved in reproduction. In other case nutrition might affect rate at which a hormone destroyed by metabolism or even the sensitivity to homrone of its target organ (Mc Donald et al, 1990). Semen characteristics were assessed for the prediction of male fertility.

Zinc is an essential nutrient for animals functioning entirely on enzymatic systems and being involved in protein synthesis, carbohydrate metabolism and many other biochemical reactions (Vallee, 1959). Next to calcium and magnesium, zinc is the most concentrated intracellular divalent cation (Keen and Graham, 1989). A field study indicated that, the usual Egyptian rations are lacking in zinc (Attia et al, 1987). Because of the scarcity of data available literature on the influence of zinc on reproductive potentials in native breeds (Zaraibi) of male goats, therefore, the present study aimed at determining the effect of dietary zinc supplementation on some reproductive performance of goats.

\section{MATERIAL-and METHODS}

Ten Zaraibi male goats aged $19-20$ months were used in the present study. They were kept at the experimental farm of Animal Reproduction Rescarch Institute, Al-Ahram, Giza Province.

At the beginning of the experiment, and for a period of 11 weeks, the animals were fed (according to NRC, 1980) on a basal diet, containing $23.36 \mathrm{mg} / \mathrm{kg}$ Zinc on dry matter basis. Semen collection was carried out weekly along the last 7 weeks, where the first 4 weeks prior to semen collection was considered as an adaptation period. After the end of the 11 weeks, the same animals were fed on the same diet supplemented with $0.019 \%$ of zinc as zinc sulphate added to the concentrate mixture $(\mathrm{Zn} \mathrm{SO} ; 36 \%$ ) of zinc group in order to increase the zinc level to about $100 \mathrm{mg} / \mathrm{kg}$ diet DM for 15 weeks. The physical and the chemical composition of the basal diet are shown in table(1).

Semen was collected weekly along the last 8 weeks. It was evaluated using the standard laboratory techniques for its volume, $\mathrm{pH}$, concentration and individual motility. Percentages of live spermatozoa and abnormal spermatozoa were counted using negrosin-eosin stained smears according to Blom, (1972). The percentages of spermatozoa with acrosomal defects were recorded in smears stained by fast green stain according to Wells and Awa (1970).

Statistical analysis:

Statistical analysis was performed according to Snedecor and Cochran (1967). 


\section{Assizu Vet. Med. J. Vol. 50 No. 101 April 2004}

Table 1: The physical and chemical composition of the experimental diet.

\begin{tabular}{|c|c|}
\hline Item & Percentage (as fed basis) \\
\hline Ingredient: & 22.93 \\
Yellow com, ground & 11.97 \\
Soya bean meal & 20 \\
Wheat bran & 13.73 \\
Berseem hay & 30.00 \\
Wheat straw & 0.807 \\
Lime stone & 0.500 \\
\hline Common salt & \\
\hline Chemical composition: & 88.6 \\
Dry matter, $\%$ & 12.4 \\
Crude protein, $\%$ & 25.98 \\
\hline Zn, ppm & \\
\hline Nutrient value: & 2.13 \\
\hline Metabolizable energy & \\
\hline
\end{tabular}

\section{RESULTS}

Data gathering in tables (2 and 3) showed the effect of dietary zine on semen characteristics in Zaraibi goats. Zine supplementation was found to be highly effective on all examined semen parameters. Semen volume $(\mathrm{ml})$, sperm concentration $\left(\times 10^{9} / \mathrm{ml}\right)$, individual motility $(\%)$ and live spermatozoa (\%) were significantly ( $\mathrm{P}<0.05)$ improved by adding zinc to the animals ration $\left(1.10 \pm 0.03 \mathrm{ml}, 5.43 \pm 0.47 \times 10^{9}\right.$, $85.75=0.55 \%$ and $88.6=0.45 \%$, respectively) than that for samples before zinc addition $\left(0.90 \pm 0.03 \mathrm{ml}, 4.62=0.64 \times 10^{9}, 80.1 \pm 0.64 \%\right.$ and $83.28=0.54 \%$, respectively). On the other hand, semen $\mathrm{pH}$, percentages of abnormal spermatozoa and those with acrosomal defects were decreased significantly $(P<0.05)$ by adding zinc to the ration of tested bucks $(6.42 \div 0.01,5.87 \pm 0.21 \%$ and $4.0 \pm 0.13 \%$, respectively) than those determined in samples before zinc addition $(6.47 \pm 0.01,7.68$ $\pm 0.26 \%$ and $4.74=0.14 \%$, respectively). Buck individualities were 
recorded as prominent $(\mathrm{P}<0.05)$ for some parameters; sperm concentration and percentages of abnormal spermatozoa $(\mathrm{P}<0.05)$.

\section{DISCUSSION}

The male reproductive function depends upon extraneous agents among which nutrition ranks first in importance. Early investigators of nutritional aspects of male fertility, particularly those concemed with problems in farm animals, relied chicfly upon examination of ejaculated spermatozoa because semen may vary quantitatively and qualitatively with diet and nutritional status of the animal (Mann and Lutwak-Mann, 1981).

Zinc has been recognized for several decades as indispensable for normal fortility, particularly in the male animal (Chaney, 1992). In the last few ycars, the research is focused on the clucidation of the the multiple functions of this nutricnt and more particularly of the beneticial effects for healtir and reproduction at doses which are much higher than nutritional requirements.

The reported increase in reproductive potentials in response to adding zinc to animal ration has been reported in bulls by Pitts et al (1966) and in buffalo by Khalifa (1997). The present work has also indicated a strong association between zine feeding and most evaluating scmen parameters.

In regard to scmen volume and concentration, the findings of the present work indicated that, dietary supplementation of Laraibi male goats with zinc resulted in a highly significant increase in ejaculate volume and concentration of spermatozoa. In agreement with our data, Hidiroglou (1979) explain the increase in cjaculate volume might be due to the normal functions of the accessory sex glands are dependant on zinc. Saleh et al. (1992) found that goat sperm density and total number of sperm per ejaculate were significantly improved after dietary supplementation with zinc. However, contradictory findings were given by Pitts et al. (1966) who did not find any significant effect of zine deficiency or supplementation on the concentration of bull spermatozoa or on total number of sperm produced.

In the current study, dietary supplementation of 7 araibi malc goats with zinc caused a highly significant decrease in $\mathrm{pH}$ of the semen. The possible cause of the significant decrease in $\mathrm{pH}$ is the stimulatory effect of zinc on biosynthesis of ascorbic acid and citric acid (McDowell, 1989 and Nagorna-Stasiak et al, 1993). 


\section{Assiut Vet. Med J. Vol. 50 No. 101 April 2004}

Concerning sperm motility, the present work demonstrated highly significant increase in individual motility. Our data may support the findings of Brandis and Granach (1990), who observed that addition of vitamins $\mathrm{C}, \mathrm{D} 3$ and $\mathrm{E}$, zinc, copper, cobalt, iodine, manganese and carotene to the daily rations of Russian Black Pied bulls resulted in an increase in the post-thawing sperm motility. Khalifa (1997) has also found an increase in individual buffalo sperm motility after dietary supplementation with zinc and vitamin E. Regarding the functional significance of zinc in relation to sperm motility, Baccotti et al (1973), claimed that, zinc was important for the mechanical properties of the accessory fibers of the sperm tail and for sperm motility. Moreover, zinc was found to regulate the metabolism of cyclic guanosine monophosphate (Santos-Sacchi et al, 1980).

With respect to percent of live sperm, the current investigation indicated that, dietary supplementation of Zaraibi male goats with zinc resulted in a highly significant increase in live sperm percent. In agreement with our records, Danek and Wisniewski (1992) on stallion, Abd El-Moneim and Tharwat (1996) on rabbit bucks and Khalifa (1997) on buffalo bulls, recorded a high percentage of live sperm in the semen of zinc-supplemented animals.

After dietary supplementation of Zaraibi goats with zinc, the present data revealed a highly significant reduction in percent of both abnormal spermatozoa and abnormal acrosome. Similar effect was observed by Brandis and Granach (1990), who reported that, daily observed by Brandis and Granach (19, copper, iodine, manganese and carotene to the rations of Russian Black Pied bulls resulted in an carotene the percentage of spermatozoa with intact acrosomes. In increase in the percentage of spermatozoa with intact acrosomes. In regard to biological effects of zinc on morphology, Mann and LutwakMann (1975), reported that, the toxicity of molecular oxygen to spermatozoa was linked to the formation of highly reactive free radical, namely the superoxoide anion radical as wextidion of the polyunsaturated peroxides which was found to induce oxidation of the poryation of the highly toxic lipid peroxides which could cause an irreversible damage to spermatozoa. Concomitantly, zinc may exert a protective effect on sperm membranes by scavenging free radicals (superoxid anions) and subsequently reduce the formation of lipid peroxide.

From this study, it can be concluded that supplementation of goat diets by $0.19 \%$ zinc over that recommended by NRC is highly effective for enhancing semen quality. 


\section{REFERANCES}

Abd El-Monem, A. E. and Tharwat, E. E. (1996): Benificial use of zine sulfate for improving semen characteristics and fertility of rabbit bucks during summer season. Proc. $9^{\text {th }}$ Cong. Egypt. Soc. Anim. Reprod., Shebin El-Kom, Menofyia. p. 44.

Attia, A. N. Awadalla, S. A. Esmail, E. Y. and Hady, M. M. (1987): Role of some microelements in nutrition of water buffalo and its relation to production. Eflect of zinc supplementation. Assiut Vet. Med. J., 18:91.

Baccotti, B., Pallini, A. and Burrini, A.G. (1973): The accessory fibers of the sperm tail. 1. Structure and chemical composition of the sperm tail. J. Submictosc. Cytol., 5:237.

Blom, E. (1972): The ultrastructure of some characteristics sperm defects and a proposal for a new classification of the bull spermiogram. VII Symp. Int. Dizootecmia, Milano, pp. 125.

Brandis, B. M. and Granach, V. G. (1990): The effect of premix and animal protein on semen quality in bulls. Zootekhniya, $6: 61$.

Chaney, S. G. (1992): Microelements. In Textbook of biochemistry with clinical correlations. $2^{\text {ni }}$ ed. Edited by Devlin, T. M., John Wiley and Sons, New York.

Chehadeh, R.Y., Ziada, M. S. Ghallab, A.M. and Seida, A.A.M. (2001). Freezability of Zaraibi goat semen in relation to different diluents, egg yolk concentration and glycerol levels. Thirteenth Ann. Cong. Egypt. Soc. Anim. Reprod. Fert. P. 189.

Danek, J. and Wisniewski, E. (I992): Changes in semen quality in Zincdeficient stallions. Medycyna Weterynaryjna, 48:566.

Hidiroglou, $M$ (1979): Trace element deficiencies and fertility in ruminants. J. Dairy Sci, 62:1195.

Keen, C. L. and Graham, T. W. (1989): Microelements. In clinical biochemistry of domestic animals. $4^{\text {th }}$ ed. Fdited by Kaneko, 3 , Academic Press, New York.

Khalifa, T. A. A. (1997). Effect of vitamin $\mathrm{E}$ and zine supplementation on sexual behavior and some semen characteristics of buffalo bulls. M.V. Sc. Vet. Thesis. Cairo Univ.

Mahmoud, M. A. (2001): Effect of stress on reproduction and maternal physiology and behaviour in sheep. pH. D. Thesis, Fac. Vet. Med. Cairo Univ. 


\section{Assiut Vet. Med.I. Vol. 50 No. 101 April 2004}

Mann I and Lutwak-Mam, C. (1975): Biology of fertilization. In Aging gametes. Edited by Blandau, R. J., Karger, Basel, Cambridge.

Mann, T and Lungk-Mann, C. (1981): Male reproductive function and semen. Springer-Verlag, Berlin, Heidelberg, New York.

Mc Doland P Fdward R.A. and Grenhalgh, J.F. (1990): Animal Nutrition $4^{\text {th }}$ edition, ELBS, Longmann, England.

McDowell, (1989): Vitamins in animal nutrition-Comparative aspects to human nutrition. Academic Press, Inc. San Diego, New York, London.

Nagoma-Stasiak, B., Lechowski, J. and Lazuga-Adamczyk, A. (1993) The effect of zinc on synthesis and absorption of vitamin $C$ in chickens. Medycyna Weterynaryjna, 49:331.

Pitts, W. J., Miller, W. J., Fosgate, O. T., Morton, J. D. and Clifton, C M. (1966): Effect of zinc deficiency and restricted feeding from two to five months of age on reproduction in Holstein bulls. $I$. Dairy Sci., 49: 995 .

Saleh I Ibrahim, A. M. and Yousri, R.M. (1992): The effect of dietary zinc, season and breed on semen quality and body weight in goats. World Rev. Anim. Prod., 27:9.

Santos-Sacchi, J., Gordon, M. and Williams, W. L. (1980): Potentiation of the CGMP- induced guinea-pig acrosome reaction by zinc. J. Experimental Zoology, 213:289.

Snedecor G.W and Cochran (1980): Statistical Methods $7^{\text {th }}$ ed. J.B.H.Publishing comp., Oxford.

Vallee, B. L. (1959): Biochemistry, physiology and pathology of zinc. Physiology Revs., 39:443.

Wells, M. F and Awa, O. A, (1970): New technique for assessing acrosomal characteristics of spermatozoa. J. Dairy Sci, 53:227. 


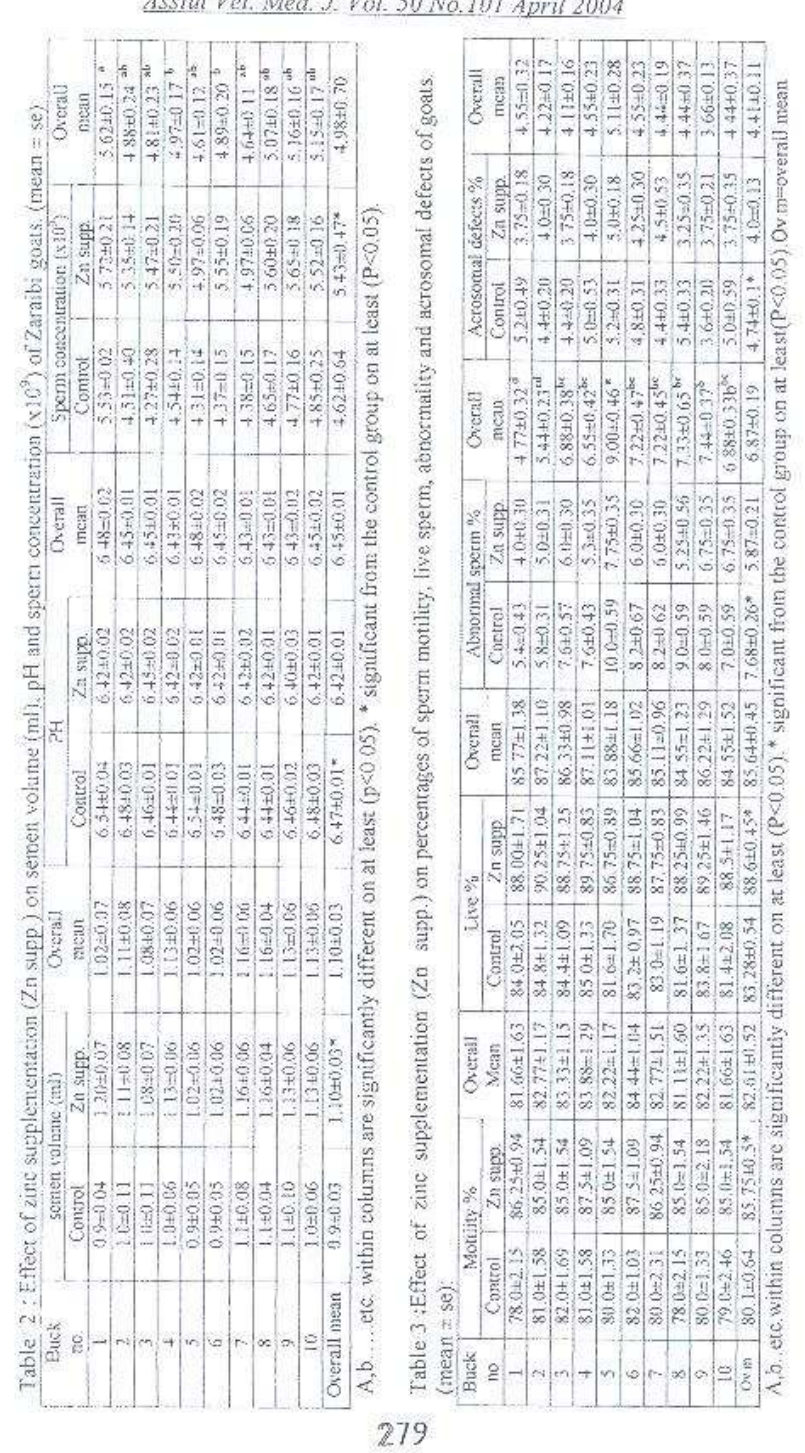

